\title{
Two new harvestman species (Arachnida: Opiliones) from the collection of Siberian Zoological Museum
}

\author{
Ава новых вида сенокосцев (Arachnida: Opiliones) \\ из комлекщии Сибирского Зоологического Музея
}

\author{
A.N. Tchemeris \\ A.H. Чемерис
}

\begin{abstract}
Department of Invertebrate Zoology, Institute of Biology, Ecology, Soil, Agriculture and Forest Sciences, Tomsk State University, Lenin avenue 36, Tomsk634010 Russia. E-mail: opiliones@mail.ru

Кафедра зоологии беспозвоночных, Институт биологии, экологии, почвоведения, сельского и лесного хозяйства, Томский государственный университет, проспект Ленина 36, Томск 634010 Россия. E-mail: opiliones@mail.ru
\end{abstract}

KEY WORDS: Opiliones, Nemaspela, Trogulocratus, new species, Abkhazia, Kyrghyzstan. КЛЮЧЕВЫЕ СЛОВА: Opiliones, Nemaspela, Trogulocratus, новын виды, Абхазия, Киргизия.

ABSTRACT. The paper presents diagnoses and descriptions of two new harvestman species: Nemaspela gagrica sp.n. $\left(\mathrm{O}^{7}\right)$ from Abkhazia and Trogulocratus kyrghyzicus sp.n. $\left(\mathrm{O}^{7}\right)$ from Kyrghyzstan. Both species are figured and their distribution is mapped.

РЕЗЮМЕ. Данная работа представляет собой диагнозы и описания двух новых видов сенокосцев: Nemaspela gagrica sp.n. ( $\left.{ }^{7}\right)$ из Абхазии и Trogulocratus kyrghyzicus sp.n. ( $\left.\sigma^{7}\right)$ из Киргизии. Оба вида иллюстрированы, и приведены карты их распространения.

\section{Introduction}

The present work is based on the opilionid material retained at the Siberian Zoological Museum of the Institute for Systematics and Ecology of Animals SD RAS, Novosibirsk, Russia. During the examination of recently acquired collections, two new species of the genera Nemaspela Šilhavý, 1966 and Trogulocratus Roewer, 1940, from Abkhazia and Kyrghyzstan respectively, have been found.

The aim of this paper is to describe and diagnose both new species. The specimens used for this study have been shared between the Siberian Zoological Museum (ISEA, curator: G.N. Azarkina) and the Zoological Museum of the Moscow State University, Russia (ZMMU, curator: K.G. Mikhailov). Abbreviations used in the text and table: Fm - femur, $\mathrm{Pt}$ - patella, $\mathrm{Tb}-$ tibia, Mt - metatarsus, $\mathrm{Tr}$ - tarsus. 'Clypeus' is the space between the ocularium and the front margin of the carapace. All measurements are in $\mathrm{mm}$.

\section{Survey of species}

Nemaspela Šilhavý, 1966

The genus Nemaspela belongs to the family Nemastomatidae and includes troglobiont species inhabiting caves of the Crimea and the Caucasus [Lebedinsky, 1914; Charitonov, 1941; Ljovuschkin, Starobogatov, 1963; Ljovuschkin, 1972; Martens, 2006]. The genus Nemaspela was recently revised by Chemeris [2009] and consists of six valid species: N. abchasica (Ljovuschkin et Starobogatov, 1963) [Russia: Krasnodar Territory; Abkhazia]; N. birsteini Ljovuschkin, 1972 [Abkhazia]; N. caeca (Grese, 1911) [Ukraine: the Crimea]; N. femorecurvata Martens, 2006 [Georgia]; N. kovali Chemeris, 2009 [Russia: Kabardino-Balkaria]; N. sokolovi (Ljovushkin et Starobogarov, 1963) [Russia: Krasnodar Territory]; see Chemeris [2009] for further details. Thus, Nemaspela gagrica sp.n. described below is a seventh species of this interesting genus.

Nemaspela gagrica sp.n.

Figs 1-6, Map 1.

Types. HOLOTYPE: $10^{7}$ (ISEA, SZM 000.0019), W Caucasus, Abkhazia, Triangle Distr., nr. Gagry Mts, Arabika Plateau, Arabika Mt., Sarma Cave, 1100 \& 1300 m a.s.1., 20.IX.2011, P.V. Rudko. PARATYPES: $1 O^{7}$ (ISEA, SZM 000.0020), together with the holotype.

ETYMOLOGY. The new species is named after the type locality, Gagry Mts in Abkhazia.

DIAGNOSIS. By its general appearance, this species is most similar to N. abchasica, N. caeca and $N$. femorecurvata, but clearly differs from all of them in 


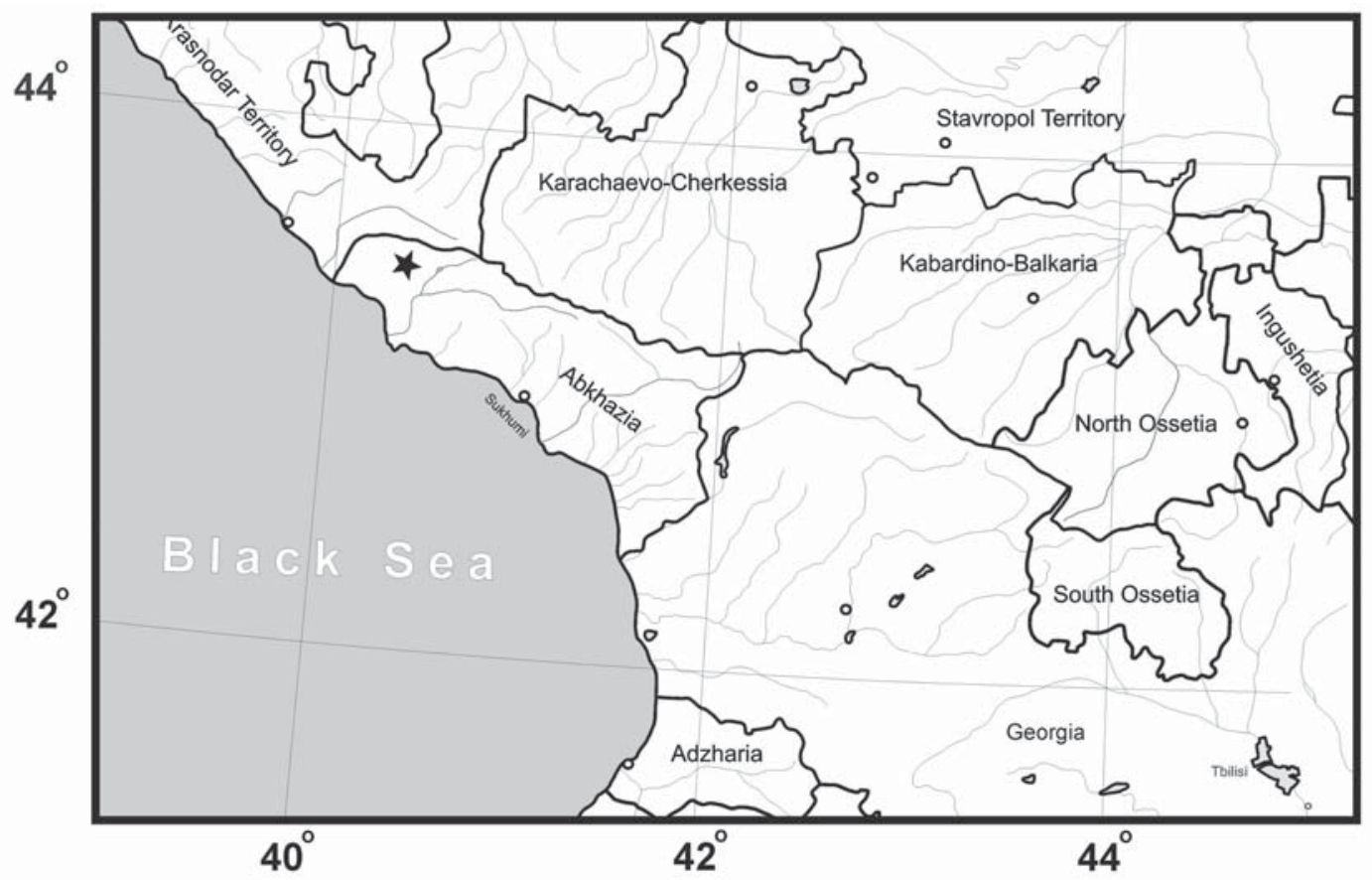

Map 1. Distribution of Nemaspela gagrica sp.n.

Карта 1. Распространение Nemaspela gagrica sp.n.
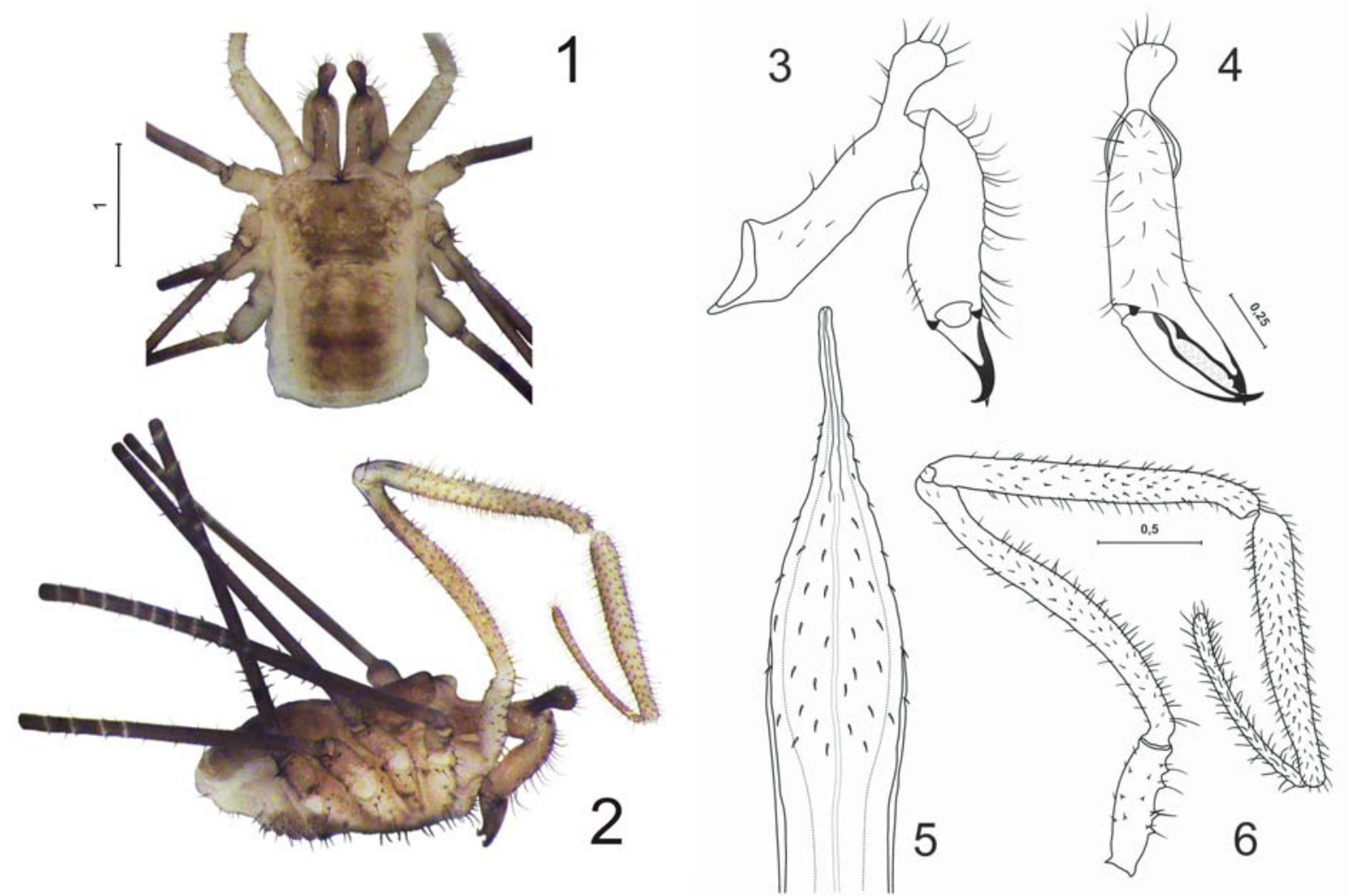

Figs 1-6. Nemaspela gagrica sp.n., male holotype: 1 - body, dorsally; 2 - body, laterally; 3 - chelicerae, laterally; 4 - chelicerae, frontally; 5 - glans, dorsally; 6 - palp, laterally.

Рис. 1-6. Nemaspela gagrica sp.n., голотип, самец: 1 - тело, вид сверху; 2 - тело, вид сбоку; 3 - хелицера, вид сбоку; 4 хелицера, вид спереди; 5 - головка пениса, вид сверху; 6 - пальпа, вид сбоку. 
Table 1. Main diagnostic characters between four Nemaspela species. Таблица 1. Основные диагностичные признаки четырех видов Nemaspela.

\begin{tabular}{|l|l|l|l|l|}
\hline \multicolumn{1}{|c|}{ Character } & \multicolumn{1}{|c|}{ N. abchasica } & \multicolumn{1}{|c|}{ N. caeca } & N. femorecurvata & \multicolumn{1}{c|}{ gagrica sp.n. } \\
\hline $\begin{array}{l}\text { Apophysis on } \\
\text { the basal } \\
\text { segment of male } \\
\text { chelicera }\end{array}$ & $\begin{array}{l}\text { Very low, peaked } \\
\text { [Chemeris, 2009: figs 22, 27; } \\
\text { Ljovuschkin \& } \\
\text { Starobogatov, 1963: fig. 4] }\end{array}$ & $\begin{array}{l}\text { Short and clavate, strongly } \\
\text { extending forward } \\
\text { [Chemeris, 2009: figs 25, 29; } \\
\text { Ljovuschkin, Starobogatov, } \\
\text { 1963: fig. 2] }\end{array}$ & $\begin{array}{l}\text { Absent [Martens, } \\
\text { 2006: fig. 14] }\end{array}$ & $\begin{array}{l}\text { Elongate and clavate, } \\
\text { strongly extending } \\
\text { forward [present } \\
\text { data], Figs 1-4 }\end{array}$ \\
\hline Palp & $\begin{array}{l}\text { Femur straight; patella } \\
\text { always shorter than the } \\
\text { femur; normal structure, } \\
\text { without tooth [Chemeris, } \\
\text { 2009: fig. 31] }\end{array}$ & $\begin{array}{l}\text { Femur straight; patella equal } \\
\text { to or slightly exceeds the } \\
\text { femur; normal structure, } \\
\text { without tooth [Chemeris, } \\
\text { 2009: fig .34] }\end{array}$ & $\begin{array}{l}\text { Femora recurved; } \\
\text { patella equal to the } \\
\text { femur [Martens, } \\
\text { 2006: fig. 14] }\end{array}$ & $\begin{array}{l}\text { Palp slightly swollen; } \\
\text { femora recurved; } \\
\text { patella shorter than } \\
\text { the femur [present } \\
\text { data], Figs 2, 6 }\end{array}$ \\
\hline Penis & $\begin{array}{l}\text { Glans slightly thickened, } \\
\text { gradually turning into long } \\
\text { stylus [Chemeris, 2009: fig. } \\
\text { 40; Ljovuschkin, } \\
\text { Starobogatov, 1963: fig. 4] }\end{array}$ & $\begin{array}{l}\text { Stylus very short, kidney- } \\
\text { shaped; glans cone-shaped, } \\
\text { sharply narrowed towards } \\
\text { stylus [Chemeris, 2009: fig. } \\
\text { 42; Ljovuschkin, } \\
\text { Starobogatov, 1963: fig. 2] }\end{array}$ & $\begin{array}{l}\text { Stylus short; glans } \\
\text { only slightly } \\
\text { thickened, gradually } \\
\text { turning into hort } \\
\text { stylus [Martens, } \\
\text { 2006: fig. 14] }\end{array}$ & $\begin{array}{l}\text { Glans sligthly } \\
\text { thickened, gradually } \\
\text { turning into long } \\
\text { stylus [present data], } \\
\text { Fig. 5 }\end{array}$ \\
\hline
\end{tabular}

the structure of the apophysis on the basal segment of male chelicerae, somewhat swollen palps and recurved palpal femora (cf. Figs 1-4, 6). By the penis structure, $N$. gagrica sp.n. is closest to N. abchasica. See also Table 1.

DISTRIBUTION: Abkhazia, the type locality only [present data].

DESCRIPTION. MALE. Measurements. Body: length 1.91; width 1.08. Cephalothorax length 0.70 . Eye tubercle width 0.22. 'Clypeal' length 0.22. Chelicera: basal segment length 0.77 ; distal segment length 0.6 ; length of forceps 0.58 ; length of aphophysis 0.23 . Penis: length 1.56; width at base 0.22 . Length of palp and legs:

\begin{tabular}{|l|c|c|c|c|c|c|}
\hline & Fm & Pt & Tb & Mt & Tr & Total \\
\hline Palp & 1.71 & 1.55 & 1.38 & & 0.98 & 5.62 \\
\hline Legs & & & & & & \\
\hline I & 4.02 & 0.71 & 2.62 & 6.01 & 2.22 & 15.58 \\
\hline II & 6.52 & 0.71 & 5.99 & 12.11 & 4.92 & 30.25 \\
\hline III & 4.31 & 0.70 & 2.71 & 6.18 & 2.62 & 16.52 \\
\hline IV & 5.33 & 0.76 & 3.71 & 8.28 & 3.31 & 21.39 \\
\hline
\end{tabular}

The body is weakly chitinized (Figs 1-2). Carapace and scutum are divided by poorly visible furrow, both are almost smooth, with hardly noticeable sculpture. Cephalotorax and tergites of abdomen without sharp borders. Abdominal sternites distinct, with a longitudinal row of hairs in the middle. Supracheliceral lamellae smooth. Rudimentary ocularium (Figs 1-2) is raised. Eyes absent. Chelicerae long, their basal segment with the clavate apophysis strongly extending forward, with hairs on its top (Figs 2-4). Distal and basal segments dorsally with hairs. Claw digits with numerous, flat micro-setae (Fig. 4). Palps (Figs 2, 6) slightly swollen, covered with short and long prominent hairs. Trochanters long and slightly bent, ventrally with 4-5 tubercles extending forward and with apical hairs. Femora recurved. Patellae shorter in length than the femora. Legs long, coxa covered with tubercles and hairs. Femora long, pseudosegments are located in the medial part of femora, with their number as follows: I - 9-13; II 17-20; III - 10-11; IV - 14-16. Claws long, crescent, identical in all four pairs. Penis long as in all Nemaspela species [see Chemeris, 2009: fig. 43]: glans sligthly thickened (Fig. 5), gradually turning into stylus; stylus long and thin, expanded at its basis; glans covered with spicules directed backward. Coloration as in other Nemaspela species [see Chemeris, 2009].

FEMALE: unknown.

\section{Trogulocratus Roewer, 1940}

The genus Trogulocratus belongs to the family Trogulidae. It can be distinguished from other trogulid genera by the number of tarsal segments and tarsal leg formula that is $2-1-3-3$. To date, the genus has been restricted to the eastern Mediterranean, with the four valid species included as follows: T. apenninicus Marcellino, 1965 (Italy); T. intermedius Roewer, 1940 (Crete); T. rhodiensis Gruber, 1963 (Greece: Rhodos); T. tunetanus Roewer, 1950 (Tunisia). The descriptions of these species and information about their distribution can be found in the following works: Marcellino [1965]; Roewer [1940, 1950]; and Gruber [1963]. The fifth new species described below represents the first record of the genus from Middle Asia.

\section{Trogulocratus kyrghyzicus sp.n.} Figs 7-16, Map 2.

Types. HOLOTYPE: $10^{7}$ (ISEA, SZM 000.0060), Kyrghyzstan, Chatkal Mt. Range, Sary-Chelek Nature Reserve, between Iiri-Kol Lake and Kuturma Pass (ca. $41^{\circ} 32.7^{\prime} \mathrm{N}, 72^{\circ} 01.0^{\prime} \mathrm{E}$ ), 2200-2400 m a.s.1., 29.05.1993, S.V. Ovchinikov. PARATYPES: $20^{7} \sigma^{7}$ (ISEA, SZM 000.0063) and $1 \sigma^{7}$ (ZMMU), together with the holotype; 2 $\sigma^{7} \sigma^{7}$ (ISEA, SZM 000.0066) and $1 \sigma^{7}$ (ZMMU), Fergana Mt. Range (N-part), S-slope of Baubash-Ata Mt., 3-5 km N of Arslanbob Vil. (ca. $41^{\circ} 22.8^{\prime \prime} \mathrm{N}, 7^{\circ} 56.6^{\prime} \mathrm{E}$ ), $2100-2400 \mathrm{~m}$ a.s.1., 18.05.1993, S.V. Ovchinikov. 


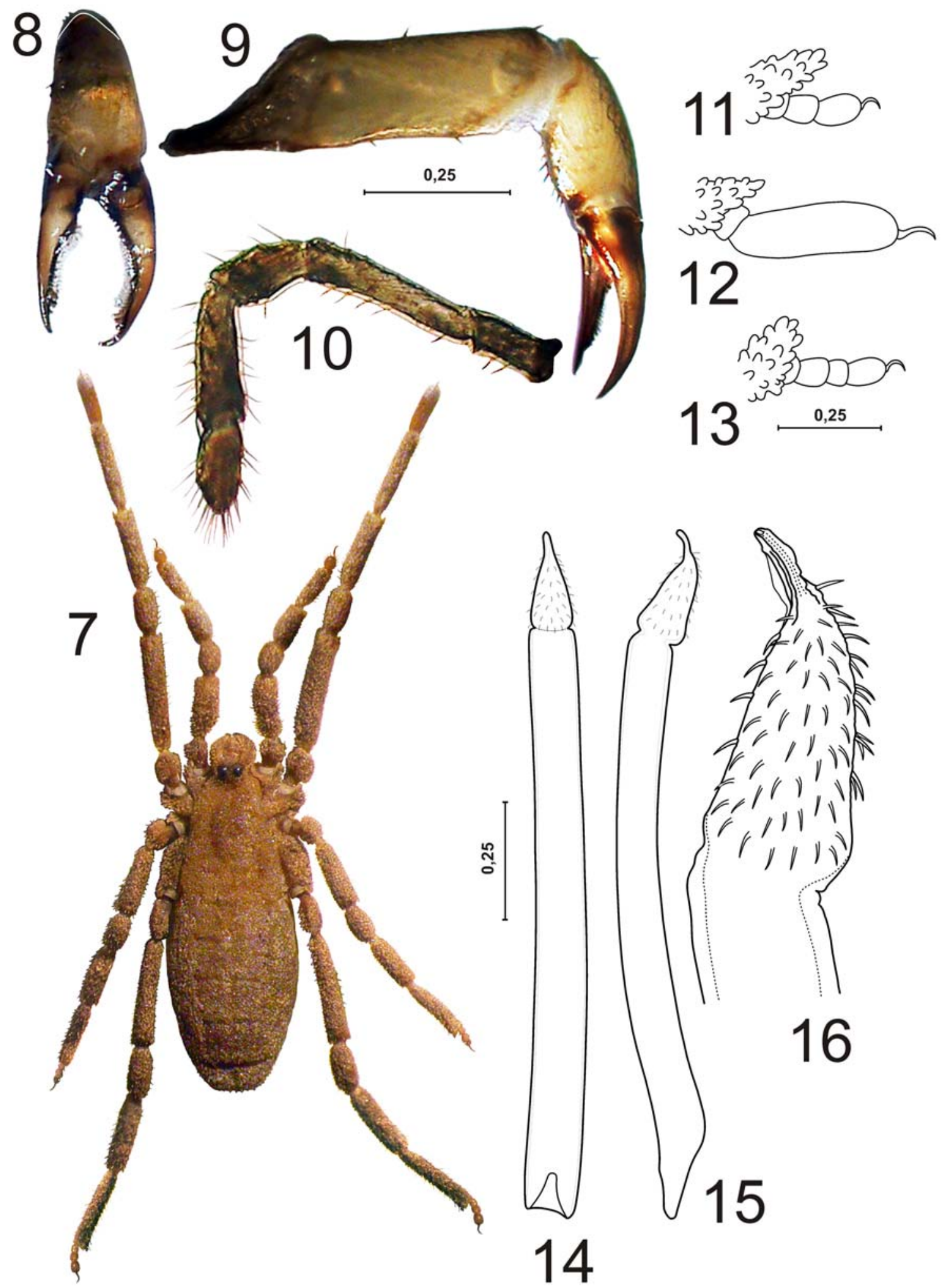

Figs 7-16. Trogulocratus kyrghyzicus sp.n., male holotype: 7 - body, dorsally; 8 - chelicerae, frontally; 9 - chelicerae, laterally; 10 - palp, laterally; 11 - tarsus of I legs; 12 - tarsus of II legs; 13 - tarsus of III and IV legs; 14 - penis, dorsal view; 15 - penis, lateral view; 16 - glans, laterally.

Рис. 7-16. Trogulocratus kyrghyzicus sp.n., голотип, самец: 7 - тело, вид сверху; 8 - хелицера, вид спереди; 9 - хелицера, вид сбоку; 10 - пальпа, вид сбоку; 11 - лапка 1-й пары ног; 12 — лапка 2-й пары ног; 13 - лапка 3-й и 4-й пар ног; 14 - пенис, вид сверху; 15 - пенис, вид сбоку; 16 - головка пениса, вид сбоку. 


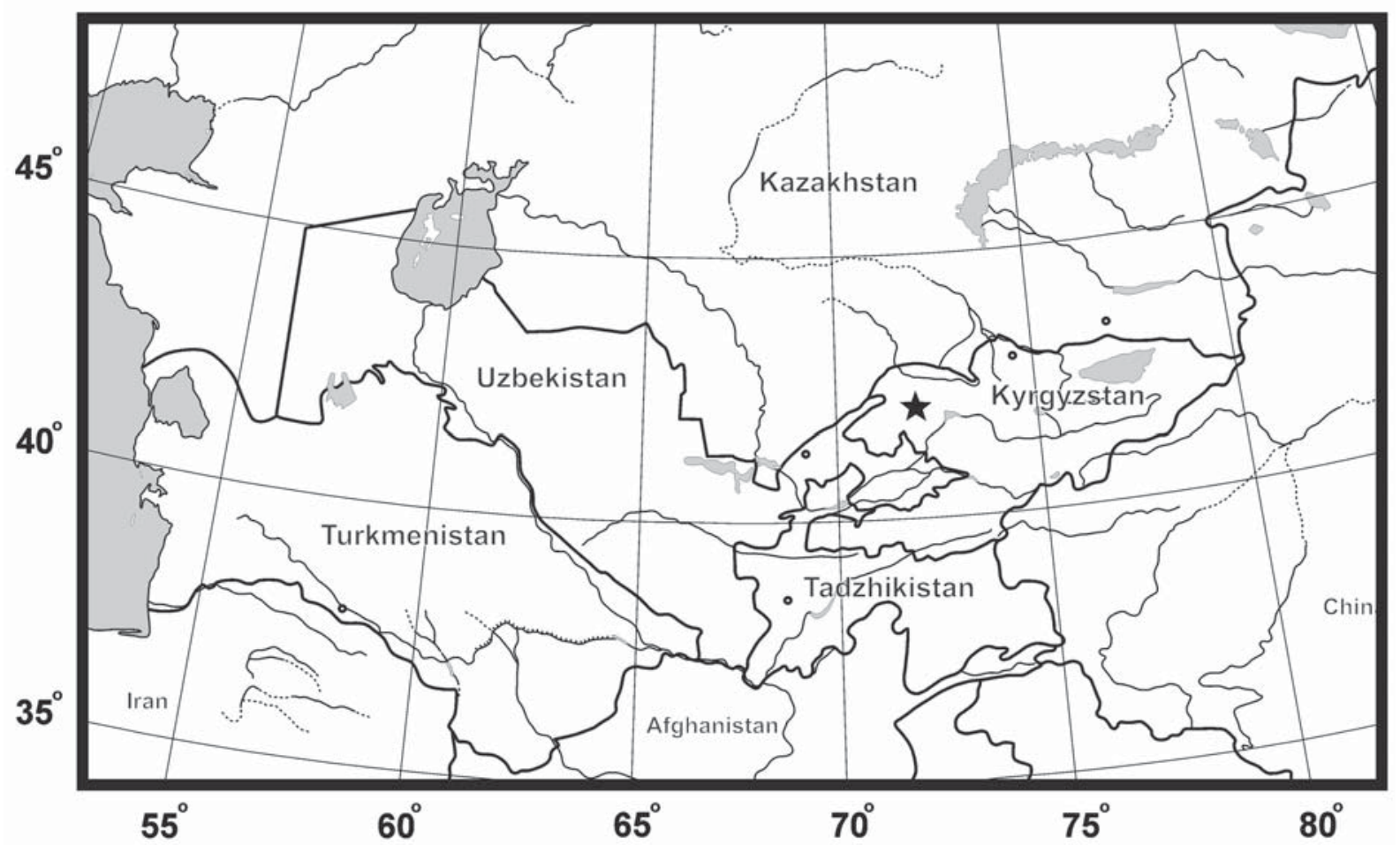

Map 2. Distribution of Trogulocratus kyrghyzicus sp.n.

Карта 2. Распространение Trogulocratus kyrghyzicus sp.n.

ETYMOLOGY. The new species is named after the country of origin, Kyrghyzstan.

DIAGNOSIS. T. kyrghyzicus sp.n. is closest to $T$. rhodiensis [cf. Rambla, 1968], but can easily be distinguished by the following characters: the glans of penis cone-shaped and the dorsum behind the hood with oval eminence (Figs 7, 11-13).

DISTRIBUTION. Kyrgyzstan [present data].

DESCRIPTION. MALE. Measurements. Body: length 5.18; width 1.84. Hood length 0.73 , width 0.68 . Distance between eyes 0.45 . Chelicera: basal segment 0.74 ; distal segment 0.35 ; length chela 0.36 . Penis: length 1.45 ; width of base 0.16 . Length of palp and legs:

\begin{tabular}{|l|c|c|c|c|c|c|}
\hline & Fm & Pt & Tb & Mt & Tr & Total \\
\hline Palp & 0.33 & 0.16 & 0.26 & - & 0.16 & 0.91 \\
\hline Legs & & & & & & \\
\hline I & 0.97 & 0.51 & 0.70 & 0.63 & 0.41 & 3.22 \\
\hline II & 1.69 & 0.75 & 1.18 & 1.26 & 0.82 & 5.70 \\
\hline III & 1.08 & 0.52 & 0.91 & 1.02 & 0.50 & 4.03 \\
\hline IV & 1.19 & 0.72 & 1.11 & 1.42 & 0.51 & 4.95 \\
\hline
\end{tabular}

Body (Fig. 7) small and robust, elongated and oval. Body integument papillose. Dorsal surface of carapace and abdominal tergites fused together forming a continuous shield. Dorsum behind the hood with oval eminence. Odoriferous glands of carapace and supra-cheliceral lamella absent. The anterior edge of carapace forms the "hood". Eyes slightly raised (without ocularium) and situated at the base of the hood. Chelicera small (Figs 8-9). Basal segment long. All segments with rare setae. Distal segment and claw equal in length. Palp relatively small and short (Fig. 10), covered with rare hairs. Patella and tarsus small and equal in length. Tarsus without claw. Legs (Fig. 7) First pair short and somewhat swollen. Femora, patellae, tibiae and metatarsi of all legs almost completely covered with hookshaped integument projections. Tarsi of all legs not polynomial. Number of tarsal segments: I - 2, II - 1, III - 3, IV - 3 (Figs 11-13). Each tarsus has a relatively long claw (Figs 7, 11-13). Penis (Figs 1415): corpus thin along its entire length, glans (Fig. 16) cone-shaped, covered with spicules. Coloration. The body and legs of living specimens covered with a continuous thin layer of sand grains and small-sized particles giving the body colour a light sandy-ochre appearance; only palps, chelicera and tarsi of legs remain free of this cover.

FEMALE: unknown.

ACKNOWLEDGMENTS. The author is extremely grateful to Mr P.V. Rudko, Mr D.A. Sidorov and Ms L.T. Kharlamova for giving access to their material collected from caves of Abkhazia and for clarifying the locality data. Dr D.V. Logunov (Manchester, UK) is thanked for general editing of the ms and help with translating it into English. 


\section{References}

Charitonov D.E. 1941. [New materials on the Arachnoidea of Abkhasian caves] // Trudy Zoologicheskogo Instituta AN GruzSSR. Vol.4. P.165-172 [in Russian]

Chemeris A.N. 2009. New data on the harvestman genus Nemaspela Šilhavý, 1966 (Arachnida: Opiliones) // Bulletin of the British Arachnological Society. Vol.14. No.7. P.286-296.

Gruber J. 1963. Ergebnisse der von Dr. O. Paget und Dr. E. Kritscher auf Rhodos durchgefhrten zoologischen Exkursionen. VII. Scorpiones und Opiliones // Annalen des Naturhistorischen Museums in Wien. Bd.66. S.307-316.

Lebedinsky Ya.N. 1914. [On the fauna of Crimean caves] // Zapiski Novorossiyskogo obshchestva estestvoispytatelei. T.40. P.113-131, Tables 1-2 [in Russian].

Ljovuschkin S.I. 1972. [Biospeologica Sovietica No. XLVI. Harvesmen of the family of Nematsomatidae from caves of the USSR] // Sbornik Trudov Zool. Museya MGU. Vol.12. P.6172 [in Russian].

Ljovuschkin S.I., Starobogatov Ya.I. 1963. [The cavernicolous Opilionidea in the Crimea and Caucasus. Biospeologica Sovietica
No. XVIII] // Byulleten’ Moskovskogo obshchestva ispytatelei prirody. Otd. Biologii. Vol.68. P.41-51 [in Russian].

Marcellino I. 1965. Su alcuni Trogulidae (Arachnida, Opiliones) della Sicilia e dell' Appennino centrale // Bollettino delle sedute dell'Accademia Gioenia di Scienze Naturali in Catania, Catania. Vol.4. No.8(5). P.323-340

Martens J. 2006. Weberknechte aus dem Kaukasus (Arachnida, Opiliones, Nemastomatidae) // Senckenbergiana biologica. Bd.86. H.2. S.145-210.

Rambla M. 1968. Algunos Opiliones del Norte de Grecia // Miscelánea Zoológica, Barcelona. Vol.2. No.3. P.1-21.

Roewer C.F. 1940. Neue Assamiidae und Trogulidae. Weitere Weberknechte X // Veröffentlichungen aus dem Deutschen Kolonial- und Übersee-Museum in Bremen. Bremen. Bd.3 Hft.1. S.1-31.

Roewer C.F. 1950. Über Ischyropsalididae und Trogulidae. Weitere Weberknechte XV// Senckenbergiana. Bd.31. Hft.1/2. S.11-56.

Responsible editor D.V. Logunov 